\title{
The life of dragonflies: order Odonata
}

\author{
Afonso Pelli' \\ Paloma Cristina Pimenta"
}

\section{Abstract}

The Odonata Order has a wide geographical distribution. The life cycle is complex, with stage of aquatic nymph, the naiad and winged adults. The research was carried out in peer-reviewed journals at the PuMed and Capes databases, with the keyword Odonata "and" ecology, when the text was complete and available. The used books were researched with insects theme, entomology, available in the collection of the library of the Federal University of the Triângulo Mineiro or private collection. The theoretical framework deals with biology, life cycle, sexual behavior and biodiversity. The Odonata order needs preserved places to reproduce and develop. Some authors mention that certain species of dragonflies can be considered good bioindicators of preserved environment, since they are sensitive to environmental changes. Finally, there is a need for further studies on taxonomy, physiology, and ethology to use this group as a bioindicator in quick works.

Keywords: Odonata, bioindicator, behavior, biodiversity.

Pós-doutora em Ecologia e Recursos Naturais; professora aposentada do Departamento de Biologia e Zootecnia da Universidade Estadual Paulista Júlio de Mesquita Filho. pesquisadora na Faculdade de Engenharia de Ilha Solteira; e-mail: elizete.lima@unesp.br

" Pós-doutor em Ciências Agrárias; professor associado da Universidade de São Paulo e daEscola de Engenharia de São Carlos; e-mail: victor.ranieri@ gmail.com 


\section{Introduction}

Insects constitute the group that dominates the planet earth, when one ponders species richness (BORROR, DELONG, 2011). They have adapted and evolved for 300 million years (BYBEE, 2016). In these adaptations there are several structural, anatomical, physiological and behavioral components that influenced and determined these successes (COSTA et al., 2011). Among these components we can mention: small size; high diversity food items; wing presence; tegument periodically changed, including layers in tegument that prevent the loss of water and prevents drowning (VEGA, VIOZZI, 2016). Reproductive capacity is extremely high, with up to tens of generations per year (MIURA, 2017). The development goes through different phases, which reduces competition among individuals of the same species (COSTA et al., 2011). But none of these characteristics is unique to insects (JOHANNSEN, 2016). The flight was developed in birds and mammals, but the insects were the first to fly (XUANKUN et al., 2015). Several other groups exchange tegument periodically, such as Nematoda or even Crustacea and Myriapoda (CORBET, 1999; MARGULIS, SCHWARTZ, 1998). Reproductive capacity is similar to some microorganisms such as protozoa, algae, bacteria and fungi (HALL et al., 2011). Crustacea exhibits more types of larvae or stages of development and does not, however, reach irradiation with the same adaptive irradiation as insects (SALT, 1963). The relationship between insects and plants was probably the key factor in success (MIURA, 2017). Among the Order of Insects, depending on the author and date approximately 30 , only five orders are considered megadiverse, that is, they have more than 80,000 species, the others have less than 40,000 species. Megadiverse are Coleoptera, Lepdoptera, Diptera, Hemiptera and Hymenoptera (CRANSTON, 2010). In these Orders the association with plants is striking (WHITEMAN, MOONEY, 2012). It is believed that when insects have reduced repellency by searching for pollinators, insects have been able to overcome barriers through simple processes, such as oxidation, reduction or hydrolysis of secondary compounds (MARGULIS, SCHWARTZ, 1998). Overcoming these barriers has experienced high adaptive irradiation and elevated adaptive irradiation, which some authors are termed coevolution (SORK, STACEY, AVERETT, 1983; KLOTH et al., 2012; BILODEAU et al., 2013; PUSTKOWIAK et al., 2017).

With time and the exploitation of natural resources, agricultural technologies and urban growth, many populations have been declining populations even before they are described (VILLALOBOS-JIMÉNEZ, DUNN, HASSAL, 2016).

The insects of the Odonata Order are usually large and showy colors, which pass the adult phase flying (BORROR, DELONG, 1964). They are popularly known as "dragonfly", "damselfly", "washerwoman" or "butt wash". They have a wide geographical distribution; in the world 5,400 species are known approximately, being 2,600 belonging to the suborder Zygopera and 2,800 the suborder Anisoptera. In Brazil, 828 species were des- cribed and distributed in 14 genera (COSTA, SANTOS, OLDRINI, 2011). In the world three suborders are found: Anisoptera, Zygoptera and Anisozygoptera (BORROR, De'LONG, 1964; COSTA, SANTOS, OLDRINI, 2011).

The earliest fossil records (Order Meganisoptera) were dated 250 million years ago (CORBET, 1999). With occupation registered until the Permian in the period of Pangea (COSTA, SANTOS, OLDRINI, 2011). The order Odonata and Ephemeroptera (ephemeral), are sisters of all other neopterous insects and are direct descendants of winged older insects. They have many indications of being few conservatives: flight, compound eyes with excellent color vision and sharpness, complex sexual behavior and life cycle involving aquatic and terrestrial environments (BYBEE, 2016).

Some species of this order need places with an optimal level of preservation to reproduce and inhabit. Researchers use dragonflies as bioindicators of a preserved environment, as this group is characterized as sensitive to environmental changes (PINTO, 2016). Researchers point out that there are many species of dragonflies that have not yet been described (GAMARRA, AOKI, DUTRA, 2013); and that little is known about the behavior and ecological relation of this Order (MIGUEL et al., 2017). Therefore, this work seeks to carry out a bibliographic survey about the Odonata Order.

\section{Methodology}

The bibliographic survey was carried out in peer-reviewed journals, at PuMed and Capes databases, with the keyword Odonata "and" ecology, when the full text was available. In books available in the collection of the Federal University of the Minas Gerais Triangle, with a search for insects and entomology. Also used personal collection books and private collection images (PELL collection - Uberaba / MG).

\section{Biology and life history of dragonflies}

In adulthood these insects can be easily identified through their body structure. The head has movement and large compound eyes very evident. There are chewing mouthpieces, large and strong jaws. The thorax vigorous, with legs facing forward, as they use their legs to catch prey during flight. It presents two pairs of membranous (hyaline) wings, in a rectangle and elongated form. The abdomen is long and narrow, with a male copulatory organ occupying the entire ventral anterior part of segments II and III. The size of individuals may be 15 to $175 \mathrm{~mm}$ in length in some Coenagrionidae and Pseudostigmatidae. They have several coloration models such as purple, green, yellow, blue, red and metallic or pigmentary colors (COSTA et al., 2011).

In compound eyes there are structures called Omathids or facets, which is capable of capturing various wavelengths of light in the photoreceptors and thus transform it into clear and "moving" images, as they see almost 250-300 frames per second, unlike humans, which distinguish only 15 frames per second. Omathids present 
themselves in different amounts in the nymph and adult phase, this is related to habitat and ecological function. Composite eyes help both in identifying their prey or rivals, and in partner selection (BYBEE et al., 2012).

Adults of the Anisoptera suborder (Fig. 1) can be identified by comparing their landing. They have a different front and rear base that guarantees a landing with open wings. The suborder Zygoptera (Fig. 2) lands with wings on the back and presents the two bases of the same wings. Anisozygoptera are restricted to the Asian region. In its landing the wings are in the intermediate position between Anisoptera and Zygoptera and the wings are similar the two suborders (SOUZA, COSTA, OLDRINI, 2007).

Figura 1. Odonata Fabricius, 1793, Suborder Anisoptera Selys, 1854, Family Libellulidae Rambur, 1842, Genus Orthemis Hagen, 1861, Species Orthemis discolor (Burmeister, 1839), kindly identified by Prof. Ângelo Barbosa Monteiro Machado; Collected in the municipality of Conceição da Alagoas/MG, rural area, at the Volta Grande Research and Development Station ( $20^{\circ} 01^{\prime} 32^{\prime}$ 'S , 48 $13^{\circ}$ ' $12^{\prime \prime} \mathrm{W}$ ), on February 7, 1997 by A. Pelli. Material deposited in the PELL collection in Uberaba/MG. Photo of the authors.

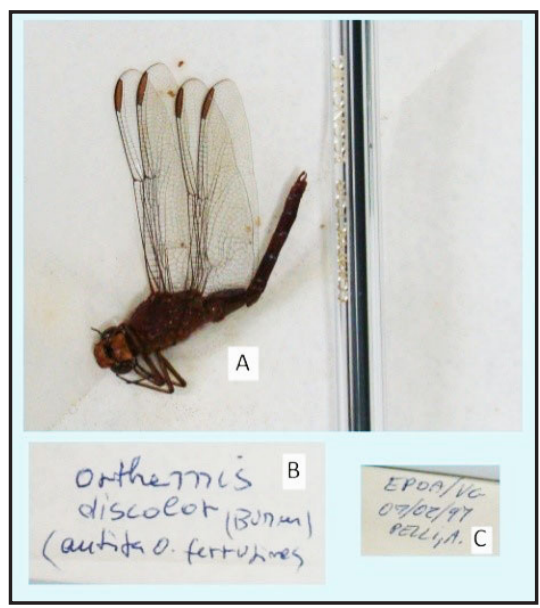

Figura 2. Exemplary of Odonata Fabricius, 1793, Suborder Zygoptera Selys, 1854, Family Lestidae Calvert, 1901, Genus Lestes Leach, 1815, Species Lestes bipupillatus Calvert, 1909, kindly identified by Prof. Ângelo Barbosa Monteiro Machado; Collected in the municipality of Conceição da Alagoas/MG, rural area, at the Volta Grande Research and Development Station ( $20^{\circ} 01^{\prime}$ '32' 'S, $48^{\circ} 13^{\prime} 12^{\prime \prime} \mathrm{W}$ ), on February 14, 1997 by A. Pelli. Material deposited in the PELL collection in Ubera$\mathrm{ba} / \mathrm{MG}$. Photo of the authors.

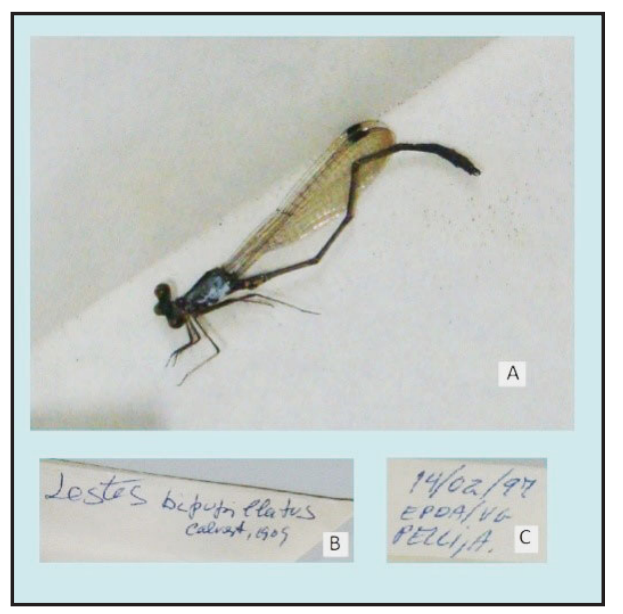

Fossil discoveries show that the most recent ancestor of the present dragonflies is the genus Epiophlebia found in the heights of the Himalayas at 1,800 to $3,500 \mathrm{~m}$. This genus has species with a vibrant appearance, different from the Anisoptera and Zygoptera (CORREARD, 2010).

\subsection{Life cycle}

At the moment of oviposition females are guided by the intensity of sunlight reflected by the surface and can perform the posture in puddles, rivers, sidewalks, streams, swamps, glasses, objects with water or even shiny and reflective surfaces (MIGUEL et al. 2017). Juveniles undergo incomplete metamorphosis, being called 'larvae' 'nymphs' or naiads and are predatory voracious in the aquatic ecosystem (LIMA, 1938). More orthodox authors choose only the term naiads, which would be aquatic nymphs. However, several authors also use the term larvae, which could cause confusion, because larvae would be used only in the type of development in which the pupa is observed. However, as the use of this term has been observed, we will also use the terms larva, nymph (FIGUEIREDO et al., 2013; NEISS, 2012; GIACOMINI, DE MARCO JR, 2008), and naiads in a free way.

The larvae are considered predators that consume any other individual, even their similar. In order to feed, there are two behaviors: sit-and-wait or active search for food. The larvae of the suborder Zygoptera, specifically the Coenagrionidae and Lestidae families, when observed in the laboratory, found preference for places with greater availability of food and few individuals competing for resources. In order to defend its territory the larva of Coenagrionidae, it can behave in the same way as the posture of eggs in which it rises forward and performs mouth attacks against the other individual, in these attacks occurs to the loss of body parts and thus hinders the larval development of the individuals (LOPES, MARCOS JR, 2000).

The larvae can be classified according to their behavior: wandering, crawling and fossorial. Wanderers live stuck in roots of submerged plants, which can be transported from one place to another. The crawlers live in the bottom on stones of the bed of rivers, streams, lakes, Iguapé among others. The fossorial ones live buried in the substrate and inhabit lotic waters (COSTA, SANTOS, OLDRINI, 2011).

Larvae may inhabit lotic or lentic sites or live in macrophytes. The greater abundance of species is found in lentic compared to lotic places, this can be attributed to the presence of more organic matter. The larvae are found using the macrophytes at various stages of development or living permanently, for example the genera Aeshna, Acanthagrion, Anax, Argia, Boyeria, Hetaerina, Lestes, Megapodagrion, Staurophlebia and Telebasis. Some species can develop in aquatic micro-systems such as trunk of hollowed-out trees and bromeliads (PINTO, 2016). The larvae of the lotic systems are more abundant in places where the current is mild and within forests or in rivers with less current (PINTO, 2016).

In some cases the larval development of Petaluridae 
and Cordulegastridae may be until 6 years. In general the development occurs in 2-3 month in various genus of libelulids (MISOF, 2002).

\subsection{Sexual Behavior}

The sexual dimorphism is common, in which males and females present morphological differences. Since in most cases males have different staining and sizes of females (COSTA, SANTOS, OLDRINI, 2011). In the Calopterygidae family, species dimorphism is common, with the female having more brownish colors and brightly colored males (BYBEE et al., 2012).

Every day males as territorialist behaviors arrive at the edge of a water source and mark their territory posing on the leaves. This will be your territory for one day. Females only visit places when the sun is warmer. When male realizes another male starts to make several very fast turns around the other but without physical contact, this process has already been observed for an hour, but usually occurs in 1.5 minutes. The action of the intruder may be to retreat or compete for territory, performing the same resource-rich movement that can offer a better advantage when choosing the female partner (LOPES, MARCOS JR, 2000).

In the Calopteryx species, the females analyze the place of ovoposition in relation to the food resource present in the habitat. The factor influencing the choice involves the existence of more leaves of plants submerged in water. The male that protects a territory with more leaves, may be the one chosen for copulation. After copulation the females introduce eggs into the vegetation along the water source. And the males remain in place for a time to aggressively defend the existing resources for their offspring (LOPES, MARCOS JR, 2000).

Sexual behavior may vary between species, but generally males prior to intercourse deposit the sperm into the copulatory tract in the abdomen and perform downward and forward movement. Sexual selection occurs when females choose the partner. A different case of reproduction occurs in the genus Ischnuran, and when the female does not copulate it then performs the parthenogenesis or polyandry, these strategies consists of reproducing hatchlings with $1 \mathrm{n}$ haploids to guarantee the survival of the species (BYBEE et al., 2016).

The reproductive behavior of these insects in some cases was observed 25 minutes of copula and during this period this pair may be perched or flying (COSTA, SANTOS, OLDRINI, 2011).

In the adult phase these insects of the order Odonata use the water to make the laying of their eggs (COSTA, LIMA, 1938). After the eggs are deposited in a water body, it occurs at seven to ten days in tropical and subtropical climates, the larvae perform three main behaviors: breathing, feeding and refuge. The distribution and abundance of the larvae have a direct relation with the substrate that can affect the presence of some Odonata species. Water bodies may present temporal and spatial changes. Some species are not found in places where changes in physical structure, organic composition, stability and heterogeneity in the substrate and debris occur (COSTA, SANTOS, OLDRINI, 2011; OLIVEIRA, TAKEUCH, CERUTTI, 2013).

\subsection{Biodiversity}

In the twenty-first century, urbanization happens uncontrollably and thus the environments are modified, devastated and polluted by the action of man. This causes the extinction of several species (VILLALOBOS-JIMÉNEZ, DUNN, HASSAL, 2016).

The lack of conservation of the biodiversity of Odonata species is due to lack of information about its importance to the environment. The scarcity of wildlife inventories in many areas does not show the true reality about the distribution and abundance of the Order (GOERTZEN, SUHLING, 2013).

The distribution of Anisoptera and Zygoptera has a strong relation with the state of preservation of aquatic environments. The suborder Anisoptera, has the largest body and needs a higher temperature for its maintenance, are found in already degraded areas. The species of the suborder Zygoptera are smaller and do not depend on a high temperature for their metabolism, so they have preference for places where there is preservation of marginal vegetation with a more shady environment (MIGUEL, et al., 2017). The most heterogeneous microhabitat presents greater species richness. Thus in homogeneous environments we have a smaller number of species (VILELA, FERREIRA, DEL-CLARO, 2016).

Their occurrence may be related to biotic and abiotic factors such as predator presence, salinity levels, acidity, solar incidence, vegetation, availability food, temperature and altitude, with different levels of habitat specificity. These insects can occupy any environment such as shallow pools, with no aquatic plants exposed to sunlight, to large pools covered by macrophytes, as well as marshes, mangroves and small pools in the shade, associated with river systems in forest areas and Veredas (PINTO, 2016).

Dragonflies are important top-chain predators in aquatic and terrestrial environments and are considered good models of study in behavioral, ecological and evolutionary research. They can be seen as species flags or umbrellas, for conservation actions (PINTO, 2016). In degraded aquatic environments, it is possible to find a large number of individuals of the Anisoptera suborder, since in these conditions they present high competitive ability (JUEN et al., 2013).

As with the other groups, the classical taxonomy is still preponderant and more accepted for the identification of the taxonomic categories (RAFAEL et al., 2012). According to some authors, identification using molecular biology techniques is promising. However, there are still no quick, practical and reliable methods available in a database (KOROIVA, et al., 2017).

However, considering that we do not yet know most of the species that are thought to exist, this moment is distant, since most species may be extinct even before we know them. 


\section{Discussion}

Throughout the article, we presented the morphological and physiological strategies that provided this group with peculiarities in evolution (VEGA, VIOZZI, 2016). The description of the way of life of the larvae and their behaviors were important to begin the studies of environmental preservation, as organic bioindicators (VILLALOBOS-JIMÉNEZ, DUNN, HASSAL, 2016).

The reproductive behavior already described in some species despite presenting general patterns, also denotes unique characteristics, not always associated with taxonomic categories. In the reproductive behaviors already identified, in some cases it is observed a territorial dispute intraspecific and sometimes interspecific; and may even result in predation or only physical damage of greater or lesser extent, such as loss of parts of a limb. The male can monitor or guard the female and ovoposition, fly during intercourse, eliminate the sperm from previous intercourse through the sperm sucking behavior, before intercourse (BYBEE et al., 2016).

In the subject of biodiversity are presented characteristics of the suborders Zygoptera and Anisoptera in relation to the presence in preserved or anthropized environments. And the studies indicate that the suborder Zygoptera is a specialist group and inhabits more preserved places, while the Anisoptera suborder is more generalist and also inhabits sites that have undergone environmental modifications (MIGUEL, et al., 2017).

Larvae and adults of Odonata are considered top-chain predators, which denotes the importance of these individuals in environments, since the absence may promote local extinction of other species and loss of diversity (COSTA, SANTOS, OLDRINI, 2011; OLIVEIRA, TAKEUCH, CERUTTI, 2013).

\section{Conclusions}

The current knowledge of the insects of the Odonata order is still very limited considering that many species have not been described, how much more to identify behaviors and to know life history or proteins produced (KOROIVA, et al., 2017).

The stages of the life cycle have been well defined but almost nothing is known about the behavior of larvae and naiads of several species. In Brazil, in some regions there is a high rate of rainfall, and these insects reproduce in ponds, lagoons, swamps and trails. The individuals of the suborder Anisoptera are classified as generalists, since they inhabit places that have already undergone anthropic actions. While Zygoptera species are mostly found only in more preserved sites being classified as specialists (COSTA et al., 2011).

The relationship of these insects with the environment is also a strong point for research, considering the gap that exists in this area; because some species are experts and depend on preserved site while others do not (LOPES, MARCOS JR, 2000; COSTA, SANTOS, OLDRINI, 2011).

\section{Acknowledgment}

The authors are grateful to the Graduate Program in Environmental Science and Technology and to Federal University of the Triângulo Mineiro for the facilities granted.

\section{References}

BILODEAU E; SIMON JC S, GUAY JF, TURGEON J, CLOUTIER C. Does variation in host plant association and symbiont infection of pea aphid populations induce genetic and behaviour differentiation of its main parasitoid, Aphidius ervi?. Evolutionary Ecology, Springer Verlag, 2013 [cited 2017 dez. 27]; 27 (1): 165 - 184. Available from: https://link-springer-com.ez33.periodicos. capes.gov.br/article/10.1007/s10682-012-9577-z.

BORROR D J, DeLONG DM. Estudo dos Insetos. Tradução de CORREIA, Diva Diniz; et al. ed. Edgard Blucher LTDA. São Paulo-SP; 1969. 69-79 p.

BORROR D J, DeLONG D M. Estudo dos Insetos. translator. CORREIA, Diva Diniz; et al. ed. Edgard Blucher LTDA. São Paulo-SP; 2011. 816 p.

BYBEE S M., JOHNSON KK, GERING EJ, WHITING MF., CRANDALL KA. All the better to see you with: a review of odonate color vision with transcriptomic insight into the odonate eye. Organisms . Rev. Eletr. Enf. [Internet]. Diversity \& Evolution. 2012. [cited 2017 set 19]; 3 (12): 241-250. Available from: https://doi.org/10.1007/ s13127-012-0090-6.

BYBEE S M. Odonata (dragonflies and damselflies) as a bridge between ecology and evolutionary genomics. Rev. Eletr. Enf. [Internet]. 2016 [cited 2017 set 19]. Available from: https://frontiersinzoology.biomedcentral.com/track/ pdf/10.1186/s12983-016-0176-7? site=frontiersinzoology. biomedcentral.com..

CORBET PS. Dragonflies: Behaviour and Ecology of Odonata. Harley Books, Colchester, UK.; translator. ed.Brill; Edição: Revised. 1999. 830 p.

CORREARD LC. Libélulas: Incríveis dragões. [cited 2017 set 26]. Available from: http://static.recantodasletras. com.br/arquivos/4011649.pdf.

COSTA JM, SANTOS TC, OLDRINI BB. Odonata. In: TRIPLEHORN CA, JONNSON NF. Estudos dos Insetos. st 7 Engl. ed.CENAGAGE Learning, translator. c2011. 816 p.

CRANSTON P S. Insect Biodiversity and Conservation in Australasia. 2010. [cited 2017 dez 27];55: 55-75. Available from: http://www-annualreviews-org.ez33.periodicos. capes.gov.br/doi/10.1146/annurev-ento-112408-085348. 
FIGUEIREDO NdSBd, PIRES M M, DAVANSO R C S, KOTZIAN C B. Diversity of larvae Odonata (Insecta) River Basin Ibicuí, Rio Grande do Sul, Brazil. Revista do Centro do Ciências Naturais e Exatas - UFSM. 2013 [cited 2017 dez 27]; 35(2): 084-094. Available from:https:// periodicos.ufsm.br/cienciaenatura/article/view/12563/7974.

GAMARRA MCT, AOKI C, DUTRA S L. Diversidade de Odonata da Reserva Particular do Patrimônio Natural Engenheiro Eliezer Batista. Rev. Eletr. Enf. [Internet]. 2013. [cited 2017 nov 21]; Available from:https:// s3.amazonaws.com/academia.edu.documents/32221873/ PageFrom_Livro_RPPN_EEB_final.pdf

GIACOMINI, HC, JR, d M. Larval ecomorphology of 13 Libellulidae (Anisoptera, Odonata) of the Middle Rio Doce Valley, Minas Gerais, Brazil/Ecomorfologia larval de 13 Libellulidae (Anisoptera, Odonata). Brazilian Journal of Biology. 2008 [cited 2017 nov 21]; 68: 219.

GOERTZEN D, SUHLING F. Promoting dragonfly diversity in cities: major determinants and implications for urban pond design. Insect Conserv. Rev. Eletr. Enf. [Internet]. 2013 [cited 2017 nov 28]; 17(2): 399-409 Available from: https://link-springer-com.ez33.periodicos.capes. gov.br/article/10.1007/s10841-012-9522-z\#citeas.

GUILLERMO-FR, BISPO PC, APPEL E, KOVALEV A, GORB, S N. Mechanism of the wing colouration in the dragonfly Zenithoptera lanei (Odonata: Libellulidae) and its role in intraspecific communication. Journal of Insect. Physiology. 812015 [cited 2017 dez 27]; 129-136. Available from:http://www.sciencedirect.com/science/ article/pii/S0022191015001584.

HALL CL, WADSWORTH NK, HOWARD DR, JENNINGS EM, FARRELL L D, MAGNUSON TS, SMITH, RJ. Inhibition of Microorganisms on a Carrion Breeding Resource: The Antimicrobial Peptide Activity of Burying Beetle (Coleoptera: Silphidae) Oral and Anal Secretions. Entomological Society of America. Rev. Eletr. Enf. [Internet]. 2011[cited $2017 \mathrm{dez} 27$ ]; 40(3): 669-678. Available from: https://academic.oup.com/ee/article-abstract/40/3/ 669/352923? redirectedFrom=fulltext.

JOHANNSEN K. Animal Rights and the Problem of r-Strategists. Ethical Theory and Moral Practice. Rev. Eletr. Enf. [Internet]. 2017. 20 (2): 333-345. Available from: https://link-springer-com.ez33.periodicos.capes. gov.br/article/10.1007/s10677-016-9774-x.

JUEN Leandro, OLIVEIRA-J JMB d, SHIMANO Y, MENDES TP, CABETTE, H S R. Composição e riqueza de Odonata (Insecta) em riachos com diferentes níveis de conservação em um ecótone CerradoFloresta Amazônica. Rev. Eletr. Enf. [Internet]. Acta Amaz. [cited $2017 \mathrm{dez}$ 27]; 44(2): 223-233. Available from:http://www.scielo.br/scielo.php?script=sci_ arttext\&pid=S0044-59672014000200008.
KOROIVA R, PEPINELLI M, RODRIGUES ME, ROQUE FdO, LORENZ-Lemke AP, KVIST S. DNA barcoding of odonates from the Upper Plata basin: Database creation and genetic diversity estimation. Rev. Eletr. Enf. [Internet]. 2017 [cited $2017 \mathrm{dez}$ 27]; 12(8): Available from: https://doi.org/10.1371/journal.pone.0182283.

KLOTH KJ, THOEN MP, BOUWMEESTER HJ, JONGSMA MA, DICKE M. Association mapping of plant resistance to insects. Trends Plant Sci. Rev. Eletr. Enf. [Internet]. 2012 [cited 2017 dez 27]; 17(5): 311-9. Available from:https://www.ncbi.nlm.nih.gov/pubmed/22322003.

LIMA C. Inseto do Brasil. Escola nacional de agronomia. 2 st ed. Editora Fdgard Blucher Ltda. translator. São Paulo;c1938.652 p.

LOPES F. S, MARCO JR PDe. Comportamento territorial em insetos: Aspectos conceituais e estudos de casos. Rev. Eletr. Enf. [Internet]. 2000 [cited 2018 jan 04];. 8: 193-222. In: MARTINS. R. P.; LEWINSOHN, T. M.; M.S.. Comportamento dos insetos, Série oecologia Brasilliensis. Available from:https://revistas.ufrj.br/index.php/oa/article/ view/7053.

MARCO JR, Paulo De, VIANNA Dana M. Distribuição do esforço de coleta de Odonata no Brasil - subsídios para escolha de áreas prioritárias para levantamentos faunísticos. Rev. Eletr. Enf. [Internet]. 2005 [cited 2017 jan 02]; 13(26). Available from: https://www. researchgate.net/profile/Paulo_De_Marco_Junior/ publication/255638978_Distribuicao_do_esforco_de_ coleta_de_Odonata_no_Brasil_-_subsidios_para_escolha_ de_areas_prioritarias_para_levantamentos_faunisticos/ links/004635351cca8ed5c7000000.pdf.

MARGULIS L, SCHWARTZ KV. Cinco reinos: um guia ilustrado da vida na terra, 3 st ed. 524; Estados Unidos, translator.Editora Guanabara Kooogan S.A., c1998. 524;

MIGUEL T B, OLIVEIRA-JUNIOR JM B, JUEN RL. Odonata (Insecta) as a tool for the biomonitoring of environmental quality. Rev. Eletr. Enf. [Internet]. ELSEVIER JOURNAL. Ecological Indicators, 2017[cited 2017 out 24]; 81: 555-566. Available from: https://www. sciencedirect.com/science/article/pii/S1470160X17303539.

MISOF B. Diversity of Anisoptera (Odonata): Infering speciation processes from patterns of morphological diversity. Rev. Eletr. Enf. [Internet]. ELSEVIER JOURNAL, 2002[cited 2018 jan 10], 105: 355-65. Available from:http://www.urbanfischer.de/journals/zoology.

MIURA K. Patterns in the autotomized adults of two sympatric, closely related grasshopper species in their natural habitat. Rev. Eletr. Enf. [Internet]. Ecological Research, 2017 [cited 2017 dez 26];. 32: 379-385. Available from: https://link-springer-com.ez33.periodicos.capes. gov.br/article/10.1007/s11284-017-1445-4. 
NEISS UG. Taxonomia de Odonata com ênfase na caracterização morfológica e biológica de larvas, na Amazonas Central, Brasil [monography]. Instituto Nacional de Pesquisas da Amazônia INPA, 2012.

OLIVEIRA E, TAKEUCHI S S, CERUTTI V E. Assembleia de Larvas de Odonata (Insecta) em ambientes límnicos do Parque Estadual de Vila Velha, Paraná, Brasil. [internet]. 2013 [cited 2017 set 25]: 163-176. Available from: www2. pucpr.br/reol/index.php/BS?dd1=12496\&dd99=pdf.

PINTO ÂP. A fauna de libélulas da América do Sul: a última fronteira a ser desvendada. Universidade Federal do Paraná, Informativo Sociedade Brasileira de Zoologia. Rev. Eletr. Enf. [Internet]. 2016 [cited 2017 set 25]; 1:7-9. Available from:https:/www.researchgate.net/profile/ Angelo_Pinto3/publication/305501848_A_fauna_de_ libelulas_da_America_do_Sul_a_ultima_fronteira_a_ ser_desvendada/links/5792400d08aeb0ffcccdb474.pdf.

PUSTKOWIAK S, CIBICKA W B, MIELCZAREK $\longleftarrow$ E, TRYJANOWSKI P, SKÓRKA $P$.The association of windmills with conservation of pollinating insects and wild plants in homogeneous farmland of western Poland. Rev. Eletr. Enf. [Internet]. 2017 [cited 2017 set 25]; 10: 1-12. Available from:https://link-springer-com.ez33.periodicos. capes.gov.br/article/10.1007/s11356-017-0864-7.

PIANKA ER. Evolutionary Ecology. Texas: Harper Collins College Publishers. Pianka E O. In: Ecologia evolutiva. Barcelona: Ediciones Orne A S.A. 1994. 5st ed. 1982.

RAFAEL JA, MELO AR, CARVALHO CJB, CASARI SA, CONSTANTINO R. Insetos do Brasil: Diversidade e taxonomia. Editora Ltda-ME, Ribeirão Preto, SP; 2012[cited 2017 dez 27];

SALT G. The defence reactions of insects to metazoan parasites. 1963 [cited 2017 dez 27]; 53: 4 -34, Disponível Available from: https://www-cambridge.ez33.periodicos. capes.gov.br/core/journals/parasitology/article/defencereactions-of-insects-to-metazoan-parasites/421CA1AD 83575BC1AB792D1DBF862CC8.

SORK VL, STACEY P, AVERETT JE. Utilization of red oak acorns in non-bumper crop year. Oecologia. 1983[cited 2017 dez 27]; 59: 49-53. Available from: https://www.ncbi. nlm.nih.gov/pubmed/25024145.

SOUZA L O I de S, COSTA J M, OLDRINI, B B. Ordem Odonata Fabricius, 1793 (Arthropoda: Insecta) in: Guia on-line de identificação de larvas de Insetos Aquáticos do Estado de São Paulo: Odonata [Internet] 1793 [cited 2017 set 22]. Available from: http://sites.ffclrp.usp.br/ aguadoce/Guia_online/Guia_on-line_Odonata_Ver \%C3\%A3o_1\%C3\%9F2.0.pdf>. Acesso em: 22 set. 2017.
VEGA RM, VIOZZI G P. The cephalic lateral line system of temperate perches (Perciformes: Percichthyidae) from Argentinean Patagonia. Journal Zoologia (Curitiba) [Internet].2016 Nov24 [cited $2017 \mathrm{dez}$ 26]. Available from: http://www.scielo.br/scielo.php?script=sci_ arttext\&pid=S1984-46702016000600900\&lng=en\&nrm=iso.

VILELA D S, FERREIRA R G, DEL-CLARO K. The odonata community of a brazilian vereda: seasonal Patterns, species diversity and rarity in a palm swamp Environment. Rev. Eletr. Enf. [Internet]. 2016[cited 2017 dez 26]; 32(2): 486-495. Available from: http://www.seer. ufu.br/index.php/biosciencejournal/article/view/30491.

VILLALOBOS-JIMÉNEZ G, HASSAL C. Effects of the urban heat island on the phenology of Odonata in London, UK. International Journal of Biometeorology [Internet]. 2017 fev 11[cited $2017 \mathrm{dez}$ 26]. Available from: https://link-springer-com.ez33.periodicos.capes.gov.br/ article/10.1007\%2Fs00484-017-1311-7.

WHITEMAN N K, MOONEY KA. Evolutionary biology: Insects converge on resistance. Macmillan Publishers Limited. NATURE. [Internet] 2012 Set 20 [cited 2019 jan 03]; Available from: http://www-nature.ez33.periodicos. capes.gov.br/articles/489376a.

XUANKUN Li, SHUANGMEI D, STEPHEN L C, ZEHUI K Y W, DING Y. The First Mitochondrial Genome of the Sepsid Fly Nemopoda mamaevi Ozerov. Rev. Eletr. Enf. [Internet]. 1997 [cited 2017 dez 27. Available from: http://web.a-ebscohost-com.ez33.periodicos.capes.gov.br/ ehost/detail/detail?vid=1\&sid=d37e0c42-19eb-491c-8af4a 10d73204113\%40sessionmgr4007\&bdata=Jmxhbmc9cHQ tYnImc210ZT1laG9zdC1saXZl\#AN=101838357\&db=aph. 